\title{
Gender Role Analysis for Institutionalizing a Women-Centric Rice Value Chain Model
}

\author{
Lipi Das, P.S. Sethy, S.K.Srivastava, S. K. Mishra*, A. C. Hemrom and S. Pattanaik \\ ICAR-Central Institute for Women in Agriculture, Bhubaneswar-751003, Odisha, India \\ *ICAR-National Rice Research Institute, Cuttack-753006, Odisha, India \\ *Corresponding author
}

\begin{tabular}{l} 
Ke y w o r d s \\
Gender gap, \\
$\begin{array}{l}\text { Awareness level, } \\
\text { Role performance, } \\
\text { Value chain model }\end{array}$ \\
\hline Article Info \\
$\begin{array}{l}\text { Accepted: } \\
20 \text { May } 2020 \\
\text { Available Online: } \\
\text { 10 June } 2020\end{array}$ \\
\hline
\end{tabular}

A B S T R A C T

\begin{abstract}
A study was conducted in Sankilo and Tentalpur villages from Cuttack district of Odisha to analyze the gender role for institutionalizing a women-centric rice value chain model and establish a comparison between men and women in rice farming with respect to awareness level, role performance, evaluation of training needs with respect to their skill gaps, establishing a correlation between the variables and developing a refined and women centric value chain which will provide a win-win situation for every stakeholder and also avoiding unusual unforeseen losses from overstocking at the market level. The results revealed that involvement of women farmers was more in case of preparation of value addition products $(95 \%)$ in comparison to other activities. It was assessed that 70 per cent of women respondents have access to FYM followed by storage, weed management etc. In access to infrastructure and machinery it was a joint access by 72.50 per cent whereas, control is 60 per cent by male members, 52.5 per cent of men and women farmers jointly had control over FYM and 27.5 per cent over manpower. In intercultural operations jointly both male and female farmers have participated but men has more control over it by 75 per cent. The awareness level among the women paddy growers was highest in case of storage, preparation of value added products, line transplanting, weed management and seed treatment. The women farmers needed training in 'Pesticide application' and 'disease management' for safe and profitable farming which ranked first.
\end{abstract}

\section{Introduction}

Rice is the staple food of Asia and part of the Pacific. Over 90 per cent of the world's rice is produced and consumed in the Asia-Pacific Region. With growing prosperity and urbanization, per capita rice consumption has started declining in the middle and highincome Asian countries. A population projection made for the year 2025 shows an average increase of 51 per cent, and in certain cases up to 87 per cent over the base year 1995. So far the annual growth rate for rice consumption in the Asia-Pacific Region over a period of 45 years (1950 to 1995) has kept pace with the demand, more through yield increase rather than area expansion. The world rice supply has more than doubled from 
261 million tonnes in 1950 (with Asian production of 240 million tonnes) to 573 million tonnes in 1997 (including the region's production of 524 million tonnes). India is one of the world's largest producers of rice and brown rice, accounting for $20 \%$ of all world rice production. Rice is India's preeminent crop, and is the staple food of the people of the eastern and southern parts of the country.

Women comprise, on average, 43 per cent of the agricultural labour force in developing countries. Women are farmers, workers and entrepreneurs, but almost everywhere they face more severe constraints than men in accessing productive resources, markets and services. This "gender gap" hinders their productivity and reduces their contributions to the agriculture sector and to the achievement of broader economic and social development goals. Agri-preneurship plays significant role in the growth and development of national economy through entrepreneurship development in crops which expands the income level and employment opportunities. So in light of the fact that rice is a predominant diet in entire India, it can be very well a productive enterprise/business for women. Rice is considered as the master crop of coastal India and in some regions of the eastern India and almost all parts of India is suitable for raising rice during the summer season provided that the water is available.

Closing the gender gap in agriculture would generate significant gains for the agriculture sector as well as for whole society by increasing agricultural productivity, reducing poverty and hunger and promoting economic growth. Rice is the major diet in whole India it can be a profitable entrepreneurship/ business for women. The main objective of the present study was to make women's work visible which they perform in value addition and also to analyze the role performance, training needs of women farmers in different activities of rice cultivation and developing a refined gender sensitive entrepreneurial model of rice value chain. In order to increase the visibility of women's productive role, especially in the case of micro-level farmers, is fundamental for ensuring their role is recognized and valued and the women are considered legitimate value chain actors and gain access to the resources and services they need to become more successful and competitive.

\section{Materials and Methods}

The study was conducted in Sankilo and Tentalpur villages under Nischintakoili block of Cuttack district of Odisha. The primary data was collected by interacting with women rice growers using a well-structured and pretested interview schedule. Stratified random sampling technique was adopted for the study of socio-economic status. For the study, 40 women rice farmers from 2 SHGs groups of these two villages were taken up. To minimize the errors, the quantitative data were collected in local units but later on they were converted into standard units. The major focus was on gender participation and their role performance in rice farming. Analysis of an existing rice value chain was also done and later refined as per the findings.

\section{Results and Discussion}

The findings relating to role performance (Table-1) of women farmers showed that the involvement of women farmers was more in case of preparation of value addition products (95\%), storage $(92.50 \%)$, weed management $(87.50 \%)$, nursery raising/sowing (65\%), transplanting (60\%) and threshing (57.50\%) where the involvement of women was significantly more than men. Whereas in procurement of inputs $(72.50 \%)$ pesticide application $(60 \%)$ and fertilizer application 
$(55 \%)$ and marketing $(47.50 \%)$ the involvement of men was found to be more.

From the above Table- 2, it can be assessed that 70 per cent of women farmers had access to FYM, whereas the same can also be seen in case of area under cultivation under joint access. It is also evident that under control over resources area is controlled by 77.5 per cent of men alone, followed by 62.5 per cent of men had control over manpower. In case of control over FYM 52.5 per cent of men and women farmers jointly had control and 27.5 per cent had control over manpower. In physical resources they had a joint access but control over the physical resources was more in case of men. Transportation is man's forte so his access and control is 90 per cent in it.
In infrastructure and machinery it was a joint access $(72.5 \%)$ whereas control is 60 per cent by men. Similarly, in intercultural operations it was joint access by both male and female farmers $(45 \%)$ but male farmers had more control $(75 \%)$ over it.

The findings presented in Table- 3 indicated that the awareness level among the women paddy growers was highest in case of storage, preparation of value added products, line transplanting, weed management and seed treatment with $100 \%$ beneficiaries, followed by summer ploughing by $80 \%$ beneficiaries. Interestingly the awareness on paddy varieties and disease management was the least with $62.50 \%$ and $60.00 \%$ beneficiaries, respectively.

Table.1 Role performance of women farmers in rice cultivation $\quad(\mathrm{N}=40)$

\begin{tabular}{|c|l|c|c|c|}
\hline Sl. No. & \multicolumn{1}{|c|}{ Activities } & Women & Men & Both \\
\hline 1. & Field preparation & $08(20.00)$ & $11(27.50)$ & $21(52.50)$ \\
\hline 2. & Procurement of Input & $05(12.50)$ & $29(72.50)$ & $06(15.00)$ \\
\hline 3. & Nursery raising/sowing & $26(65.00)$ & $04(10.00)$ & $10(25.00)$ \\
\hline 4. & Transplanting & $24(60.00)$ & $07(17.50)$ & $09(22.50)$ \\
\hline 5. & Fertilizer Application & $04(10.00)$ & $22(55.00)$ & $14(35.00)$ \\
\hline 6. & Pesticidal Application & $04(10.00)$ & $24(60.00)$ & $12(30.00)$ \\
\hline 7. & Weed management & $35(87.50)$ & $02(05.00)$ & $03(07.50)$ \\
\hline 8. & Irrigation & $14(35.00)$ & $10(25.00)$ & $16(40.00)$ \\
\hline 9. & Harvesting & $23(57.50)$ & $07(17.50)$ & $10(25.00)$ \\
\hline 10. & Threshing & $04(10.00)$ & $09(22.50)$ & $27(67.50)$ \\
\hline 11. & Cleaning and Winnowing & $37(92.50)$ & $00(0.00)$ & $03(07.50)$ \\
\hline 12. & Storage & $13(32.50)$ & $19(47.50)$ & $08(20.00)$ \\
\hline 13. & Marketing & $15(37.50)$ & $11(27.50)$ & $14(35.00)$ \\
\hline 14. & Sale decision & $38(95.00)$ & $01(02.50)$ & $01(02.50)$ \\
\hline 15. & Prep of value addition products & & $10(25.00)$ & $16(40.00)$ \\
\hline
\end{tabular}

(The number in the parentheses indicate percentage) 
Table.2 Access to and control over farm resources by respondents $(\mathrm{N}=40)$

\begin{tabular}{|c|c|c|c|c|c|c|c|}
\hline \multirow[t]{2}{*}{ Sl. No. } & & \multicolumn{3}{|c|}{ Access } & \multicolumn{3}{|c|}{ Control } \\
\hline & & Men & Women & Both & Men & Women & Both \\
\hline \multirow[t]{7}{*}{1.} & \multicolumn{7}{|l|}{ Resources } \\
\hline & $\begin{array}{l}\text { Area under } \\
\text { cultivation }\end{array}$ & $10(25.00)$ & $02(05.00)$ & $28(70.00)$ & $31(77.50)$ & $04(10.00)$ & $05(12.50)$ \\
\hline & FYM & $04(10.00)$ & $28(70.00)$ & $08(20.00)$ & $11(27.50)$ & $08(20.00)$ & $21(52.50)$ \\
\hline & Seed & $18(45.00)$ & $10(25.00)$ & $12(30.00)$ & $21(52.50)$ & $04(10.00)$ & $05(12.50)$ \\
\hline & Irrigation & $24(60.00)$ & $07(17.50)$ & $09(22.50)$ & $24(60.00)$ & $07(17.50)$ & $09(22.50)$ \\
\hline & Fertilizers & $13(32.50)$ & $06(15.00)$ & $21(52.50)$ & $21(52.50)$ & $04(10.00)$ & $05(12.50)$ \\
\hline & Manpower & $10(25.00)$ & $07(17.50)$ & $23(57.50)$ & $25(62.50)$ & $04(10.00)$ & $11(27.50)$ \\
\hline \multirow[t]{6}{*}{2.} & \multicolumn{7}{|l|}{ Credit } \\
\hline & Capital & $20(50.00)$ & $05(12.50)$ & $15(37.50)$ & $30(75.00)$ & $04(10.00)$ & $06(15.00)$ \\
\hline & Bank Credit & $21(52.50)$ & $04(10.00)$ & $15(37.50)$ & $31(77.50)$ & $04(10.00)$ & $05(12.50)$ \\
\hline & $\begin{array}{l}\text { Expenditure in } \\
\text { critical input }\end{array}$ & $21(52.50)$ & $04(10.00)$ & $15(37.50)$ & $25(62.50)$ & $04(10.00)$ & $11(27.50)$ \\
\hline & Income & $0(0.00)$ & $33(82.50)$ & $07(17.50)$ & $0(0.00)$ & $40(100.00)$ & $0(0.00)$ \\
\hline & Savings & $0(0.00)$ & $33(82.50)$ & $07(17.50)$ & $0(0.00)$ & $40(100.00)$ & $0(0.00)$ \\
\hline \multirow[t]{6}{*}{3.} & \multicolumn{7}{|c|}{ Physical resources } \\
\hline & $\begin{array}{l}\text { Infrastructure/ } \\
\text { Machinery }\end{array}$ & $07(17.50)$ & $04(10.00)$ & $29(72.50)$ & $24(60.00)$ & $04(10.00)$ & $12(30.00)$ \\
\hline & Transportation & $36(90.00)$ & $04(10.00)$ & $0(0.00)$ & $36(90.00)$ & $04(10.00)$ & $0(0.00)$ \\
\hline & $\begin{array}{l}\text { Intercultural } \\
\text { operations }\end{array}$ & $18(45.00)$ & $04(10.00)$ & $18(45.00)$ & $30(75.00)$ & $04(10.00)$ & $06(15.00)$ \\
\hline & Harvesting & $11(27.50)$ & $07(17.50)$ & $22(55.00)$ & $12(30.00)$ & $10(25.00)$ & $18(45.00)$ \\
\hline & $\begin{array}{l}\text { Post- harvest } \\
\text { Practices }\end{array}$ & $12(30.00)$ & $08(20.00)$ & $20(50.00)$ & $10(25.00)$ & $08(20.00)$ & $22(55.00)$ \\
\hline
\end{tabular}

(The number in parentheses indicate percentage) 
Table.3 Awareness level of women farmers involved in rice farming $\quad(\mathrm{N}=40)$

\begin{tabular}{|c|l|c|c|c|c|c|}
\hline $\begin{array}{c}\text { Sl. } \\
\text { No. }\end{array}$ & \multicolumn{1}{|c|}{ Awareness level } & $\begin{array}{c}\text { Fully } \\
\text { Aware }\end{array}$ & $\begin{array}{c}\text { Partially } \\
\text { Aware }\end{array}$ & $\begin{array}{c}\text { Not } \\
\text { Aware }\end{array}$ & $\begin{array}{c}\text { Mean } \\
\text { score }\end{array}$ & Rank \\
\hline 1. & Storage & $40(100.00)$ & $0(0.00)$ & $0(0.00)$ & 2.0 & I \\
\hline 2. & Line planting & $40(100.00)$ & $0(0.00)$ & $0(0.00)$ & 2.0 & I \\
\hline 3. & Seed treatment & $40(100.00)$ & $0(0.00)$ & $0(0.00)$ & 2.0 & I \\
\hline 4. & Fertilizer application & $30(75.00)$ & $10(25.00)$ & $0(0.00)$ & 1.8 & III \\
\hline 5. & Summer ploughing & $32(80.00)$ & $8(20.00)$ & $0(0.00)$ & 1.8 & III \\
\hline 6. & Pest management & $31(77.50)$ & $9(22.50)$ & $0(0.00)$ & 1.8 & III \\
\hline 7. & Diseases management & $24(60.00)$ & $16(40.00)$ & $0(0.00)$ & 1.6 & IV \\
\hline 8. & Suitable variety of paddy & $25(62.50)$ & $15(37.50)$ & $0(0.00)$ & 1.6 & IV \\
\hline 9. & Preparation of value added product & $40(100.00)$ & $0(0.00)$ & $0(0.00)$ & 2.0 & I \\
\hline 10. & Weed management & $40(100.00)$ & $0(0.00)$ & $0(0.00)$ & 2.0 & I \\
\hline
\end{tabular}

(The number in parentheses indicate percentage)

Table.4 Training needs of women farmers according to their skill gaps $\quad(\mathrm{N}=40)$

\begin{tabular}{|c|l|c|c|c|c|}
\hline $\begin{array}{c}\text { Sl. } \\
\text { No. }\end{array}$ & \multicolumn{1}{|c|}{ Activities } & Yes & No & $\begin{array}{c}\text { Mean } \\
\text { score }\end{array}$ & Rank \\
\hline 1. & Summer ploughing & $28(70.00)$ & $12(30.00)$ & 1.7 & III \\
\hline 2. & Fertilizer application & $30(75.00)$ & $10(25.00)$ & 1.8 & II \\
\hline 3. & Preparation of value added products & $24(60.00)$ & $16(40.00)$ & 1.6 & IV \\
\hline 4. & Intercultural operations & $25(62.50)$ & $15(37.50)$ & 1.6 & IV \\
\hline 5. & Pesticidal application & $40(100.00)$ & $00(0.00)$ & 2.0 & I \\
\hline 6. & Disease management & $40(100.00)$ & $00(0.00)$ & 2.0 & I \\
\hline
\end{tabular}

(The number in parentheses indicate percentage)

Fig.1 Modified women-centric Rice Value Chain (RVC) Model

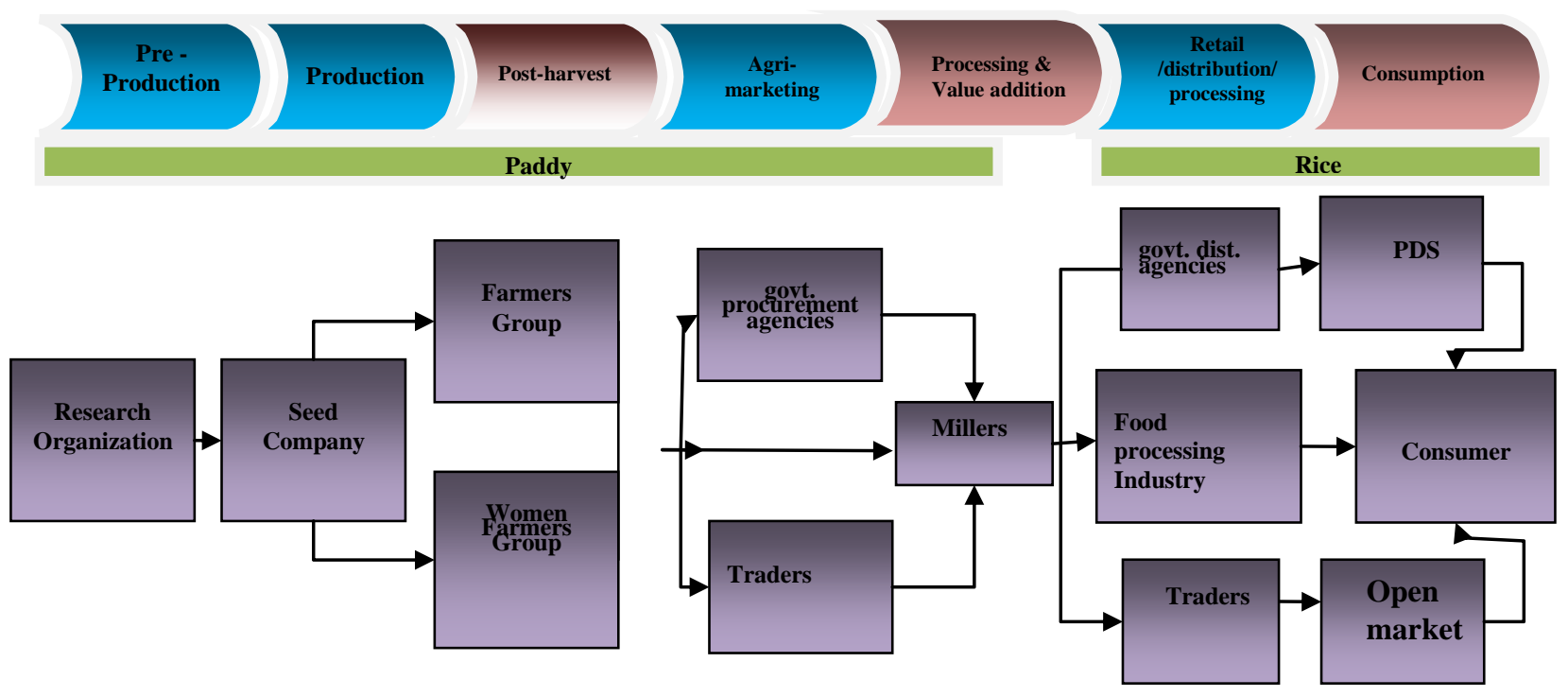


The ranking of the training needs among the respondents in Table- 4 showed that 'pesticide application' and 'disease management' for safe and profitable farming were ranked first followed by 'fertilizer application' and 'summer ploughing' which were ranked II and III, respectively. Similarly preparation of value added products and summer ploughing ranked least among all. While establishing a correlation between the dependent and independent variables it is noteworthy to mention that that occupation was alone found to have positive and significant relation with all the three dependent variables of role performance, training needs and awareness level.

A modified, refined and women-centric Rice Value Chain (RVC) was developed during the study for maximum benefit of the paddy growing women farmers after analyzing the value chain model developed by Directorate of Agriculture and Food Production, Govt. of Odisha (2017-18). The chain starts form preproduction phase where the role of Research Organizations (Both Govt. and Private Players) has been defined in which the Research Organizations play the role of breeder seed provider for the seed companies. After the multiplication of breeder seeds the seed is then supplied to the WFGs (Women Farmer Groups) or farmer groups for grain production purpose in large scale. Once the production is done the WFGs (Women Farmer Groups) and farmer groups would directly sell the produce to government procuring agencies, millers and traders. The government procuring agencies and the traders thereby can again transfer or sell the produce to the millers for milling activities further only to be bought by government distributing agencies, traders and food processing industries. While the government distributing agencies through public distribution system make it reach to the end user i.e., the consumers, the food processing industries through their retail chain market reach the product to the consumers and the traders indirectly reach the consumers through open retail market which further goes down to small shops and outlets before reaching the consumers. This value chain provides a winwin situation for every stakeholder. While the information flow is also very crucial which first flows from the consumer side creating demand and reaches to the research organizations for consumer specific breeder seed and thus consumer specific end product reaches the consumer ensuring fair an profitable business for all the stakeholders and also avoiding unusual unforeseen losses from over stocking at the retail and market level.

In conclusion, the role of female farmers in field is same as men except transport and procurement process. There is joint involvement in access of resources, credit and others but control of men was more over them. Women farmers were fully aware of summer ploughing, time line of fertilizer application and stages of value addition as these were ranked highest among the awareness level ranking followed by suitable variety of paddy for their location but least aware about the critical periods and dough stage of paddy cultivation.

\section{References}

Acharya, S.S. and Agarwal, N.L. 2004. Agricultural Marketing, New Delhi, Oxford and IBN Publishing Co. Pvt. Ltd.

Akhter, T. 2009. Value Chain Analysis of Dairy Sector in Rangpur District. M.S. Agricultural Economics (Marketing) Thesis, submitted to the Department of Agribusiness and Marketing, Bangladesh Agricultural University, Mymensingh. Bangladesh.

Anna, N. 2006. Supply Chain Network 
Economics: Dynamics of Prices, Flows, and Profits, Edward Elgar Publishing, 2006.

Dooren, I. C. 2005. Rice value Chain Analysis. International Fair Trade Association. 43707E8E-090C-286777. DOC-CVD.

Feller, A., Dan S., and Tom, C. 2006. Value
Chains Versus Supply Chains, (Accessed at http://www.b ptrends.com).

Government of Malawi 2009. Staple Foods Value Chain Analysis, Country Report, November 2009, Chemonics International Inc, Malawi.

\section{How to cite this article:}

Lipi Das, P.S. Sethy, S.K.Srivastava, S. K. Mishra, A. C. Hemrom and Pattanaik, S. 2020. Gender Role Analysis for Institutionalizing a Women-Centric Rice Value Chain Model. Int.J.Curr.Microbiol.App.Sci. 9(06): 2561-2567. doi: https://doi.org/10.20546/ijcmas.2020.906.311 